https://doi.org/10.18485/iipe_60nam.2021.ch25

\title{
THE NON ALIGNED MOVEMENT AND REFORM TENDENCIES IN THE UNITED NATIONS
}

\author{
Duško DIMITRIJEVIĆ ${ }^{1}$
}

\begin{abstract}
From the historical experience so far, it can be seen that the United Nations has stimulated the emergence and development of the NonAligned Movement. The United Nations was a universal political forum in which non-aligned states could develop their activities and pursue their interests together with the interests of the international community as a whole. The world organisation provided opportunities in which the policy of non-alignment could be affirmed and in which the bloc pressures of the East and the West could be resisted. Expressing solidarity with the interests of Third World countries that had similar historical experiences with colonialism and economic and social backwardness, led to the merging of political identities into the identities of non-aligned countries. In that sense, the United Nations played a decisive role because it enabled the rapprochement of states that gained independence and freedom from the yoke of former colonial powers in the process of decolonisation. Acting under the auspices of the United Nations, the non-aligned countries have been actively involved in solving key political, economic and social problems in the world. In this way, the United Nations became their significant stronghold, an irreplaceable system for achieving their goals and principles, and an important instrument for justifying their real strength in international relations. This should come as no surprise, as the basic aims and principles of non-alignment were in line with the aims and principles
\end{abstract}

\footnotetext{
${ }^{1}$ Professorial Fellow, Institute of International Politics and Economics, Belgrade. E-mail: dimitrijevicd@diplomacy.bg.ac.rs.

The paper presents findings of a study developed as a part of the research project "Serbia and challenges in international relations in 2021", financed by the Ministry of Education, Science, and Technological Development of the Republic of Serbia, and conducted by the Institute of International Politics and Economics, Belgrade.
} 
contained in the United Nations Charter. As a fundamental legal basis for international relations from the end of the Second World War until today, the Charter has enabled the gradual implementation of the specific goals and principles of the Non-Aligned Movement. The ability of the nonaligned countries to acquaint the world with their specific goals and principles through the United Nations system indicated the democratic basis of the world organisation, which in many segments was more receptive to non-aligned and underdeveloped countries than to those "aligned" or developed. Membership in the United Nations has therefore had a positive effect on the cohesion of the non-aligned countries, by developing awareness of the possibilities of a unified solution to common problems and open international issues. The active participation of the NonAligned Movement in the activities of the United Nations and its agencies has grown over time with the increasing number of the non-aligned countries in the membership of the world organisation. With an impressive and numerically superior voting power, the Non-Aligned Movement has practically influenced the course of international relations inside and outside the United Nations system. Its significant contribution to the reform processes of the world organisation has to some extent influenced the reshaping and strengthening of the role of the United Nations in contemporary international relations.

Key words: Non-Aligned Movement, United Nations, reform tendencies, Security Council, General Assembly, Economic and Social Council.

\section{Introduction}

A wide range of issues that the Non-Aligned Movement has faced over the past decades, and which have been discussed additionally more at eighteen conferences of Heads of State or Government: in Belgrade (Yugoslavia) - 1961; in Cairo (Egypt) - 1964; in Lusaka (Zambia) - 1970; in Algiers (Algeria) - 1973; in Colombo (Sri Lanka) - 1976; in Havana (Cuba) - 1979; in New Delhi (India) - 1983; in Harare (Zimbabwe) - 1986; in Belgrade (Yugoslavia) - 1989; in Jakarta (Indonesia) - 1992; in Cartagena (Colombia) - 1995; in Durban (South Africa) - 1998; in Kuala Lumpur (Malaysia) - 2003; in Havana (Cuba) - 2006; in Sharm el-Sheikh (Egypt) 2009; in Tehran (Iran) - 2012; in Porlamar (Venezuela) - 2016, and in Baku (Azerbaijan) - 2019, can be sublimated to one general question: How to transform the world on a just and democratic basis? (Final Documents, 1961, 1964, 1970, 1973, 1976, 1979, 1983, 1986, 1989, 1992, 1995, 1998, 2003, 2006, 2009, 2012, 2016, 2019). 
Since the beginning of its existence, the Non-Aligned Movement has given a significant place to the United Nations. Namely, the Movement believed that the world organisation had a real role in creating and building a new and fairer international order. In this sense, the impact of the ideas of the United Nations, its goals and principles regarding the preservation of peace and security and the creation of such a system of international relations within which all members of the international community should be equal in their rights and duties in order to build a more democratic, just and prosperous order, was crucial to the historical evolution of the NonAligned Movement. By accepting the ideas, goals and principles of the United Nations and incorporating them into its political doctrine and practice, the Non-Aligned Movement affirmed universal values such as the struggle for international peace, the development of friendly relations between the states and the peoples, and the development of international cooperation in addressing international economic, social, cultural and humanitarian issues.

The aspirations of the Non-Aligned Movement for the transformation of the international order have their roots in the so-called Ten principles of Bandung, which were proclaimed in the final Communique at the Conference of Asian-African Countries in 1955 (Bogetić, 2019, p. 31; Tadić, 1976, p. 142; Mates, 1970, pp. 249-250). These principles, which have become the main parameters for membership in the Non-Aligned Movement, include the principles of respect for fundamental human rights and for the purposes and principles of the Charter of the United Nations, respect for the sovereignty and territorial integrity of all nations, recognition of equality of all races and of the equality of all nations large and small, abstention from intervention or interference in the internal affairs of another country, respect for the right of each nation to defend itself singly or collectively, in conformity with the Charter of the United Nations (which assumes abstention from the use of arrangements of collective defence to serve the particular interests of any of the big powers and abstention by any country from exerting pressures on other countries), refraining from acts or threats of aggression or the use of force against the territorial integrity or political independence of any country, settlement of all international disputes by peaceful means, such as negotiation, conciliation, arbitration or judicial settlement as well as other peaceful means of the parties' own choice, in conformity with the Charter of the United Nations, promotion of mutual interests and cooperation and respect for justice and international obligations. By accepting and later elaborating these principles in its political practice, the Non-Aligned Movement has shown that it will not remain a 
passive factor in international politics, but will have an independent role based on affirming the principles that represent its "quintessence" and within the United Nations system. In an attempt to quell bloc conflicts and complete the decolonisation process, the Non-Aligned Movement advocated within the United Nations for the recognition of national liberation and anti-colonial movements. The main goals of the non-aligned were focused on supporting the realisation of the people's selfdetermination, achieving their national independence, and then building states through the protection of independence, sovereignty and territorial integrity. Bringing new energy into the work of the world organisation and in the progressive construction and codification of legal rules of the new post-war international order, the Non-Aligned Movement became the main guardian of independence from all forms of colonialism, neocolonialism, imperialism, hegemony, and against all manifestations of aggression, domination, racism and torture in international relations.

Guided by the principles and goals of the UN Charter, the Non-Aligned Movement built its own ideological and institutional platform, which it needed to achieve its own goals and principles. ${ }^{2}$ In this sense, the United Nations was for the Non-Aligned Movement the mainstay and instrument through which it could fulfil its role in the creation and transformation of

2 Six years after the Bandung Conference, the First Summit of the Non-Aligned
Movement was held in Belgrade, Yugoslavia, from September 1 to 6,1961 . At this
Summit, closer cooperation of the non-aligned countries was initiated, which from
the seventies of the last century until today, gradually took on the appropriate
institutional outlines of international organisations. However, it should be
acknowledged that the Non-Aligned Movement does not operate like other
international organisations and does not formally have a structure typical of
intergovernmental organisations. The movement has no formal constitutional act
and no permanent secretariat. In recent years, the Movement has established a
Coordination Bureau at the ministerial level and at the level of permanent
representatives who regulate internal activities and activities in United Nations
bodies. The Bureau is led by the Permanent Representative of the Chairman-in-
Office to the United Nations. The decisions of the Movement are reached by
consensus at the Summits of Heads of State or Government, which are usually
convened every three years. The administration of the organisation of these
Summits is the responsibility of the presiding state. The foreign ministers of the
member states meet periodically at conferences. Otherwise, they meet regularly
at the opening of each regular session of the UN General Assembly. There are also
appropriate workings, experts, technical and other groups within the Movement. 
the international order. Acting through the United Nations system, the NonAligned Movement in the given circumstances of the Cold War (but also in the post-Cold War period), learned a lot on the realisation of unique goals concerning preserving world peace and security and promoting friendly relations and international cooperation. Membership in the United Nations prevented the isolation of the non-aligned countries and developed their cohesion on the basis of their own political orientation, which arose from the idea of coexistence of formally equal all nations and sovereign states. The realisation of the principles and respect for the obligations arising from the Charter of the United Nations has led to the profiling of a special nonaligned policy, which includes the idea of active peaceful coexistence (Bartoš, 1955, pp. 17-19; Mates, 1974; Petković, 1974). ${ }^{3}$ Active peaceful coexistence carried a visionary picture of a future international order that the non-aligned countries want to create together with other countries, regardless of differences in socio-political and economic systems and belonging to a particular civilization or cultural group. ${ }^{4}$ Hence, the participation of different states in regulating international relations points to the fact that active peaceful coexistence has served the Non-Aligned Movement as a political alternative in regulating the global issues of the international community (Blagović, 1973, pp. 34-42). In that sense, regardless of the crises into which the Non-Aligned Movement fell from time to time (so-called crises of continuity and authority), as well as regardless of the fact that it remained somewhat limited by narrow regional or continental political frameworks (via the so-called tricontinental platform), its role in the progressive development of the principle of active peaceful coexistence, as

${ }^{3}$ The principle of non-alignment and peaceful coexistence derives from the Panchsheel principles, first formulated in the 1954 Agreement on trade and intercourse between Tibet Region of China and India, and which affirms the principles of territorial integrity and sovereignty, non-aggression, non-interference in internal affairs, equality and mutual benefit and peaceful coexistence. Starting from this political platform, Presidents Tito and Nehru in their joint statement from the same year formulated non-alignment as active realization of political and economic intentions, peaceful ideological coexistence and military detachment, which could have a significant impact on the course of world affairs.

${ }^{4}$ In this sense, in accordance with its views on the future international order, the Non-Aligned Movement calls for the protection of cultural differences and tolerance of religious, socio-cultural and historical peculiarities that define human rights in a particular region. The Non-Aligned Movement thus draws strength from the diversity of the entire global society. 
well as in the democratisation of international relations and in the building of a new and fairer international order, it has remained its main determinant since the First Belgrade Summit in 1961, until today (Bogetić, 2019, Dimić, 2011, p. 5.). ${ }^{5}$

As a "protean movement", the Non-Aligned Movement developed within and outside the United Nations system in response to the constant flow of the modern international order (Stojanović, 1981, pp. 443-450). However, only in the United Nations did the Non-Aligned Movement exercise its true power through important political and legal decisions and through direct communication with the Great Powers and developed countries. The number of its members in the world organisation enabled the more active participation of the non-aligned countries in the bodies and agencies of the United Nations, and thus the increased influence of the NonAligned Movement in world politics. Of course, the interpenetration of the Non-Aligned Movement and the world organisation was expressed in the harmonization and complementarity of the principles and goals of the UN Charter with the policy of the Non-Aligned Movement and in the contribution of this policy to strengthening the role and place of the United Nations in international relations (Komatina, 1981, p. 11). In this sense, the United Nations was also the most effective political forum for cooperation through which the Non-Aligned Movement could actively act to accelerate the process of democratisation of the international community.

\footnotetext{
${ }^{5}$ According to the Yugoslav position, the policy of active peaceful coexistence, despite the strong ideological influence, included universal premises which can be reduced to the following: 1) The position that small countries, especially "nonengaged" are not competent to participate in world politics and contribute to solving international problems; 2) The view that the destiny of the world is indivisible and that hence there are deep common interests, obligations and responsibilities of "big" and "small" countries; 3) The belief that conservative regimes have no future, that their time is up and that in the background of the arms race and the Cold War is an attempt to prevent the defeat of capitalism by force and "stiffen" the development and spread of socialism (as Tito said, "that victory march progress and transformation of the world"); 4) The knowledge that we need to look realistically at the regulation of international relations in the age of nuclear weapons, space exploration, accelerated technological development, scientific achievements and unprecedented life opportunities.; 5) The need to concentrate all peaceful efforts in order for "lasting peace" to prevail over the catastrophe brought about by the war conflict of the Great Powers.
} 
Due to inherited relations in the world embodied in the irreconcilable aspirations of developed and underdeveloped countries, uncoordinated interests of the countries of the Global North and Global South, strategic goals of large and small countries, or in general, due to insufficient maturity of political and social conditions, the influence of the Non-Aligned Movement in the United Nations has waned over time. In that sense, the position of the United Nations itself was somewhat ruined since the world organization found itself at a crossroads where it had to decide whether to follow the path of democracy and the rule of law, or to be satisfied with the "relativisation" of the international legal order? This is all the more so because the development of democracy and the rule of law is a precondition for achieving human progress related to solving crucial international issues in the economic and social sphere such as sustainable development and eradication of poverty and hunger, prevention of pandemics, natural disasters, environmental pollution, climate change and migration, prohibition of proliferation of weapons of mass destruction, nuclear disarmament, combating terrorism and international crime, and protecting all human rights and fundamental freedoms (Damian-Lakićević, 2009, p. 497). As this key issue for humanity refers to the consistent, dedicated and balanced fulfilment of the goals and principles of the United Nations Charter and general international law, it is believed that this issue can be resolved only by the collective action of all relevant world actors. In this sense, the Non-Aligned Movement recognised the need for further deepening and by expanding increasingly dynamic relations with other world actors such as the G8, the Group of 77, the European Union, and so on, in order to intensify mutual cooperation and alleviate the gap that exists between the Global North and the Global South. The results of the last Non-Aligned Movement Summit held in Baku in 2019 illustrate these efforts as the non-Aligned Movement member states have clearly reaffirmed their commitment to implementing United Nations goals and principles in their international cooperation activities and in strengthening international peace and security. Recognising that the United Nations has a central role to play in the multilateral solution to the burning global problems and challenges facing humanity, the Non-Aligned Movement stressed that responsibility must be shared in a balanced way through the fulfilment of the international obligations contained in the UN Millennium Declaration of September 2000, then at the World Summit for Social Development held in Copenhagen in 1995, at the World Summit on Sustainable Development held in 2002, in the World Summit Outcome Document of 2005, in the outcome of the 2010 High Level Plenary Meeting on Millennium Development Goals, in the 
outcome document of the Rio +20 Conference on Sustainable Development entitled "Future We Want" of 2012, in the outcome of the third UN World Conference on Disaster Risk Reduction held in Sendai 2015, in General Assembly's resolution 70/1 of 25 September 2015, entitled "Transforming our World: the 2030 Agenda for Sustainable Development ", in the Addis Ababa Action Agenda of the Third International Conference on Financing for Development held in Ethiopia 2015, in the Paris Agreement adopted under the UN Framework Convention on Climate Change of 2015, in the New Urban Agenda, adopted at the UN Conference on Housing and Sustainable Urban Development - Habitat III, held in Ecuador 2016, and at the High-Level UN Conference on South-South Cooperation held in Buenos Aires 2019 (Final document, 2019, pp. 36, etc).

Bearing in mind that the correction of political mistakes from the past is no longer possible, the member states of the Non-Aligned Movement, along with other interested states, have put themselves in the function of generally improving the capacity of major United Nations bodies. Given the continuity of the Non-Aligned Movement, it can be assumed that the Movement will continue to support and reaffirm the goals and principles of the world organisation while participating in the reform of its institutional system, whose binding factor and fundamental international legal basis remains the United Nations Charter (Dupuy, 1997, Šahović, 1998, pp. 239). ${ }^{6}$ For the non-aligned states, it is not disputed that the United Nations has no alternative. The earlier inefficiency of the main bodies of the United Nations has led to the belief that its structure no longer corresponds to political reality. However, in the previous period, the demands for changing its power structure did not go in favour of achieving optimal solutions. Neither the functional powers of the main bodies of the United Nations, nor their organisational structure, were to blame for that, but the responsibility lay on the wider disunity of the states and their unwillingness to implement appropriate political and legal reforms. The traditionally great ideological, political, economic and cultural differences, as well as the strong desire of the permanent members of the Security Council to preserve their privileged position stemming from the ruins of World War II, are a good example.

${ }^{6}$ The interdependence between the application of the objectives and principles of the United Nations and the reform of the Security Council would most likely entail the amendment of the Charter within the meaning of the provision of Article 108. 


\section{Reform tendencies in the Security Council}

Starting with the Eleventh Summit of Heads of State or Government held in Cartagena - 1995, through the Summit in Durban - 1998, Kuala Lumpur - 2003, Havana - 2006, Sharm el-Sheikh - 2009, Tehran - 2012, Porlamar - 2016 and finally in Baku - 2019, the Non-Aligned Movement concluded that the most important issue in the reform of the United Nations is the structural and functional reorganisation of the Security Council (Final Documents, 1995, 1998, 2003, 2006, 2009, 2012, 2016, 2019).

Earlier efforts by the non-aligned countries to recompose this major United Nations political body date back to the decolonisation process that began after World War II when new emancipated states on the African, Asian and American continents began to put more serious pressure on the United Nations, demanding Security Council reform (Mikhailtchenko, 2004, p. 2). ${ }^{7}$ The request was not supported for opportunistic reasons and due to the fact that its influence on the special rights of the Great Powers was not explained. The new proposal arrived from 44 countries in Asia and Africa in 1963. Based on the mentioned proposal, the General Assembly adopted Resolution no. 1991 (XVIII), 17 December 1963, which changed the number of non-permanent members of the Security Council from six to ten (Jovanović, 1989, p. 217). The enlargement of the Security Council has led to changes in its way of working. By increasing the number of members from eleven to fifteen, the importance of this solution also increased, because it was much harder for the permanent members of the Security Council to impose their "individual or collective will" in the "more or less visible" way (Avramov, 1965, Dimitrijević, 2009)..$^{8}$ Since the 1970s, the Non-Aligned Movement has increasingly insisted on Security Council reform. Namely,

\footnotetext{
${ }^{7}$ The first formal proposal came from 18 Latin American countries in 1956.

${ }^{8}$ These structural changes did not lead to a change in the competences of the Security Council, nor did they have any influence on the decision-making process, which remained dependent on the special rights of the great powers. The amendments confirmed the nomination system, so that 10 non-permanent members are elected according to the regional formula. 5 non-permanent members are elected from Asia and Africa, 2 from Latin America, while 1 member is elected from Eastern Europe and 2 from Western Europe and other countries (including the countries of the British Commonwealth, Canada, New Zealand, Australia, which are not belonged to the above groups). Every year, 5 new members are elected according to the rotation system, thus enabling greater fluctuation in the composition of this body.
} 
by the resolution of the General Assembly 34/431 of 14 December 1979, it was decided to put the issue of Security Council reform on the agenda. No progress was possible, due to the well-known fact that the Cold War between the Great Powers was in full swing and that the possibility of any changes was immediately suspended. After the fall of the "Iron Curtain", the situation seemed to change drastically. The Security Council ceased to be a stage on which the conflict of the Great Powers took place and became a much more efficient body whose actions were to lead to further democratisation of the world organisation. Yet, due to the fact that since the early 1990s it has relied heavily on leading Western states that have provided it with unnecessary material support in maintaining collective security, the role of the Security Council has often been called into question by both developed and the non-aligned countries, precisely because of the inexplicable motives that determined it actions in practice. From there came numerous proposals from the non aligned states and regional bodies to reconsider the function of the Security Council, and to organisationally encourage certain structural and functional reforms that would lead to greater efficiency, effectiveness and fairness of its work.

Due to the complex and far-reaching consequences of the reform of the Security Council, on 3 December 1993, the General Assembly formed the Open-ended Working Group on the question of equitable representation on and increase in the membership of the Security Council and other matters related to the Security Council. The program of activities of the Working Group was divided into two sets of reform issues, namely, in relation to issues related to the enlargement of the Security Council, decision-making, periodic reviews, and then in relation to issues related to improving publicity, participation of non-permanent members in its the work and relations between the Security Council, the General Assembly and other United Nations bodies, including issues of support, restriction and abolition of veto rights, as well as the possibility of amending the Charter (Dimitrijević, 2009; Müller, 1997, p. 88; Kumar Jha, 1994). The debates conducted within the Working Group and the presented proposals, together with the final reports from the Summit of the Non-Aligned Movement, today represent important sources for a clearer view of the political and legal positions of individual states, regional groups and international organisations. What can be noticed on the basis of time distance is that the Working Group systemised the presented proposals into three possible variants of the Security Council reform. The first group of proposals refers to immutability in relation to the existing permanent membership (the socalled status quo model), which would be applied only for a limited period of 
time in the absence of a specific agreement on the comparative expansion of permanent and non-permanent membership of the Security Council. The second group of proposals includes the possibility of expanding both permanent and non-permanent membership which cannot go to the detriment of the already existing permanent members (the so-called model of parallelism), while the third group is a special variant of the previous solution (the so-called model of the region) which provides for the expansion of non-permanent membership solely on the basis of establishing the principles of sovereign equality and equitable geographical representation (Winkelmann, 1997, pp. 39-50; Dimitrijević, 2007, pp. 935-958; Report of the Open-ended Working Group, 2001, pp. 62-65).

The Non-Aligned Movement advocated a second model in which each region of the southern hemisphere (Africa, Asia and Latin America) would have one permanent seat on the Security Council. Adhering to a fundamentally fair regional approach that ensures the stability and indivisibility of the organisation, the Non-Aligned Movement supported the proposal to expand the Security Council from five permanent and six non-permanent seats. Welcoming the candidacy of Japan and Germany for permanent membership in the Security Council, the Non-Aligned Movement advocated that representatives from other, less developed regions of the world be represented in the permanent membership. In the event that the presented idea could not be realised, the Non-Aligned Movement proposed that the expansion of the total number of new nonpermanent members of the Security Council be expanded from five to eleven (UN Doc. A/49/965, 18/9/1995, pp. 94, 96). ${ }^{9}$ Considering that states are elected to the Security Council primarily on the basis of their contribution to the maintenance of world peace and security (which is not always practical and measurable) and then on the basis of their equitable geographical representation (which includes representing the interests of countries in the region), the voluntaristic dimension of increasing its membership remained a constant of all proposals and debates to its structural reform. This is, after all, quite visible in the reports submitted by the then UN Secretary General Boutros Boutros-Ghali in the early 1990s.

Reports entitled:"An Agenda for Peace Preventive diplomacy, Peacemaking and Peace-Keeping", and "An Agenda for Development"

\footnotetext{
${ }^{9}$ Cuba suggested a slightly smaller number than the Non-Aligned Movement, without clearly explaining how the eight new members would share seats in the Security Council.
} 
show that changes in the physiognomy of Security Council membership continue to be one of the central themes of all proposals for reform of the world organisation (UN Doc. A/47/277 - S/24111, 1992; UN Doc. A/48/935, 6 May 1994). Also, in the report of Secretary-General Kofi Annan of 21 March 2005, entitled: "In Larger Freedom: Towards Development, Security and Human Rights for All", which set out the High Level Panel's joint proposals on the fair representation and increase of membership in the Security Council remained conditioned by the political compromise of its permanent members (UN Doc. A/59/2005, pp. 42-43). Looking from the current perspective of the proposed reform proposal, two separate models can be discerned.

The first model (model $A$ ) envisages the increase of the Security Council with six new permanent seats, two seats each for the countries of Africa and the countries of Asia and the Pacific, and one seat each for the countries of Europe and both Americas. In relation to the number and schedule of nonpermanent members, the model plans to expand the Security Council by three additional seats in accordance with the regional key and rotation system every two years. Hence, based on the mentioned schedule, the region of "Africa" would get four, the region of "Asia and the Pacific" three, the region of "Europe" two and the region of "America" four non-permanent members. The number of permanent members would be increased from the current five to eleven, with the current permanent members, unlike the new permanent members, retaining the right of veto. The reason for accepting the proposed model is that none of the existing permanent members would want to give up the acquired right of veto. If the new members get the right of veto, it will be impossible to achieve one of the basic goals of the reform, which refers to increasing the efficiency of the Security Council, because the work of the Security Council could be slowed down, if not paralyzed. Finally, with the "model A", the number of non-permanent members would rise from ten to thirteen out of a total of twenty-four seats (fifteen current and nine new). Each of the large regional groups would have six seats, but with a different status.

The second model (model B) does not envisage new seats for the permanent members of the Security Council. On the contrary, the model proposes the introduction of eight new seats for the category of nonpermanent members with a four-year renewable term. One additional seat for non-permanent members with a two-year term that cannot be renewed is also envisaged. In the distribution of seats according to the system of rotation of non-permanent members with a four-year mandate, each regional 
group should have two representatives. The distribution of seats of the nonpermanent members with a two-year mandate assumes that Africa is represented by four, Asia and the Pacific by three, Europe by one and America by three representatives of the countries in the region. According to "model B", out of the total number of twenty-four seats in the Security Council, each region would be represented by six seats of different status.

Regarding the presented models of the Secretary General, the permanent members of the Security Council with the right of veto, who are able to individually block the reform, were at least restrained in assessing their possible application in practice. On the other hand, the countries aspiring to become permanent members of the Security Council, which were originally gathered within the G4 group consisting of Germany, Japan, Brazil and India, and with the accession of South Africa, Egypt and Nigeria within the group 7+, clearly and openly stated the demands for the implementation of the Security Council reform. This was also understandable, because for them, resolving the reform issues is prejudicial in relation to the issue of strengthening personal status in international relations. In this regard, the discussion on the reorganisation of the Security Council outlined strategic goals that should be confirmed in the future, in line with other agreed goals (Šahović, 2005). However, mutual doubts and animosities, most certainly among the permanent members of the Security Council, have contributed to slowing down the process of adopting the United Nations reform package - a unique and useful instrument, which in the future should pave the way for a complex system of multilateral negotiations. Nevertheless, despite the stated fact, the achievement of common goals regarding the reform of the Security Council was not interrupted, but continued. ${ }^{10}$ In its annual reports, the Non-Aligned Movement supported the continuation of the debate on this important

${ }^{10}$ In this regard, it should be noted that the Non-Aligned Movement in principle supported some of the reform proposals of the current UN Secretary General Antonio Guterres, who since 2017, presented a series of interrelated proposals involving economic and social development of the world in accordance with the guidelines contained in Agenda 2030 and within the strategic UN Development Assistance Framework, then in the field of redesign and restructuring of collective security, which should contribute to a more coherent, pragmatic, agile and efficient system of world peace, as well as in the management of the administrative apparatus of the world organisation which provides for the decentralisation of decision-making powers and the direction of policies and processes that should lead to increased accountability and transparency. 
global issue, believing that the issue of Security Council reform should be considered as part of a package and in line with the Millennium goals promoted by heads of state and government on 8 September 2000 . Advocating for the intensification of all aspects of Security Council reforms based on the principles of sovereign equality and equal geographical representation, as well as the needs and democratisation of its working methods, including the decision-making process, the Non-Aligned Movement stressed the need for a comprehensive approach. In that sense, the participation in the work of the Working Group examined the possibility of reforming the functional powers of the Security Council, i.e. their "adaptation" to the requirements of the time.

As is well known, the provisions of the Charter give the Security Council special powers and competencies with regard to the peaceful settlement of disputes (Chapter VI), taking action in case of threat to peace, violation of peace and acts of aggression (Chapter VII), use of regional agreements and organisations (Chapter VIII), administration and supervision of Trust Territories (Chapter XII). The motives for the transfer of basic functions to a narrower body, such as the Security Council, are contained in the view that through the Council as an operational-political body it is possible to achieve a greater degree of efficiency of the world organisation. Starting from the assumption that the Great Powers have greater political responsibility in making decisions related to peace and security than other members of the United Nations, a situation has been created that enables the concentration of power and centralization of monopolies of force in the hands of a narrow circle of elected states. This antinomy between the political and legal aspects of collective security in the Charter is supported by the "free consent" of other members of the Security Council. In international practice, this situation cannot relieve the Great Powers of their responsibility to act in accordance with the provisions of the Charter, i.e. in synchrony with the goals and principles of the United Nations (Bowet, 1994, p. 92). It follows from the above that the functional organisation of the Security Council as the executive-political body of the United Nations does not reflect the equality of its institutional and normative aspects. The division of competencies, in which the powers in the field of peace and security are primarily concentrated within its framework, has not fully withstood the test of time. The reasons are, inter alia, that the Charter does not provide for the possibility of replacing the permanent members of the Security Council and does not contain any provisions on expanding their number. Likewise, the Charter does not prescribe criteria for determining which countries in the world are eligible to become members of an "exclusive club" 
(Dimitrijević, 2009). In eliminating contradictions, it is necessary to provide certain mechanisms by which this situation will be resolved. The flow of opportunities with responsibilities previously required solving the problem of reforming the collective security system (Šahović, 2005; Dimitrijević, 20052006). Given the real geopolitical changes that took place in the world after the post-Cold War era, the Non-Aligned Movement advocates that the process of collective security reform be redirected towards the real empowerment of the United Nations to meet the challenges of the new age. ${ }^{11}$ In this sense, it is first necessary to note that the use of force in new circumstances requires new and more precise rules. In recent years, states have often violated the general rule prohibiting the use of force and threats. The expansion of the scope of activities of the Security Council was therefore inevitable. The ideas of a New World Order and Global Governance in the field of peace and security had significant political implications, especially in the international community where conflicts were mitigated during the Cold War. At the same time, looking from the perspective of the Charter, three situations arose in practice. The first concerned the use of force for prevention, based on the right to self-defence when the threat was not imminent (pre-emptive use of force). The second situation referred to the preventive use of force in conditions when the threat potentially or actually existed, but outside the state borders (preventive use of force). The third situation also involved the use of force in the event of a threat, within the borders of the national territory. All three situations were "covered" by

11 The development tendencies of the United Nations collective security system led to the formation of the Peacebuilding Commission. The establishment of the Commission was encouraged by the High Panel of Experts. Due to the divided competence in the matter of preserving peace and security, the initiative was first supported by the Security Council on the basis of Resolution 1645 of 20 December 2005, and then that proposal was supported by the General Assembly in Resolution 60/180 of 30 December 2005. The main task of the Peacebuilding Commission is to take action in post-conflict countries whose governments are seeking the help of the international community to resolve the difficult postconflict situation. With the establishment of the Peacebuilding Commission, for the first time in its history, the United Nations has established a body whose mission in the field of collective security relies on the professional capacities of the world organisation. As an advisory body, the Commission proposes action plans to be followed in the countries involved in peacekeeping operations. The Commission does not have the possibility to take actions within the framework of peacekeeping operations on its own. 
Security Council resolutions. In a wide range of objectives, resolutions have become the main instruments through which the Security Council has acted in cases where it has been determined that this would be politically expedient (Blokker, 200, 541-563). The Non-Aligned Movement considers that such conduct was largely contrary to its mission as set out in the United Nations Charter (Fassbender, 2005, pp. 14, etc; UN Doc. A/RES/60/1, para. 152-154). ${ }^{12}$

In its final report from the recent conference, the Non-Aligned Movement has established that the Security Council must act in an emergency, nonselectively, impartially and responsibly, and strictly adhere to the powers and functions conferred on it by the Charter. In particular, this means that the Security Council must avoid applying Chapter VII of the Charter as an umbrella to address issues that do not necessarily pose a threat to international peace and security (Final document, 2019). In other words, the Security Council, in its resolutions, should more clearly define the principles on which the use of force in international relations would be based. This, under completely changed conditions could reaffirm the central role of the Security Council in the universal system of collective security and reaffirm the right to authorize military intervention as a last resort in the event of serious threats such as genocide and other mass crimes, ethnic cleansing or serious human rights violations. Also, the Non-Aligned Movement would have to oppose attempts by the Security Council to impose or extend sanctions against any state under the pretext or with the aim of achieving the political goals of one or more states. The Non-Aligned Movement also supported the proposal for the Security Council to envisage a mechanism that would consider all aspects and real effects of sanctions against a country, including in the framework of the application of Article 50 of the Charter. This is all the more so because the application of sanctions has profound consequences not only for the country to which the sanctions are applied, but also for neighbouring countries and trading partners. In addition, the Non-Aligned Movement stressed the need to minimise the harmful effects

${ }^{12}$ The direction of further developments in the reform of the Security Council was determined at the summit of heads of state and government held in September 2005. The final document, entitled "World Summit Outcome Document", reaffirmed the Security Council's existing role in preserving world peace and security and highlighted the need to reform it in order to achieve broad representativeness, efficiency and transparency, which could contribute to effectiveness and the legitimacy of his decisions. 
of the imposed sanctions, as well as to clearly define the goals, deadlines and humanitarian aspects related to the normal life of the civilian population (Milinković, 1996, p. 151). The Non-Aligned Movement especially emphasised the need not to allow misinterpretation of the provisions of the Charter of Self-Defence in situations where instead of collective intervention of the Security Council, the individual preventive intervention of states outside their borders is applied without a real threat to their security.

In order to achieve democratisation, transparency and efficiency of the Security Council, it is necessary to achieve a balance in the work of the main bodies of the United Nations. This is especially true in cases where the Security Council expands its functions and powers at the expense of the General Assembly and the Economic and Social Council (Strydom, 2007, pp. 1-46). All non-aligned states (including those involved in the activities of the Caucus of the Non Aligned Movement), should promote and defend the above-mentioned positions and goals during their mandate in the Security Council. Finally, Security Council reform should be comprehensive and address all substantive issues, including membership, regional representation, the Council's agenda, its working methods and decisionmaking process, including the use of vetoes, which should gain the widest possible political acceptance by the members in accordance with the provisions of the Charter and the relevant decisions and resolutions of the General Assembly (Final document, 2017, 2018, 2019). ${ }^{13}$

\section{Reform tendencies in the General Assembly}

In the previous historical period, the General Assembly remained the most democratic political, advisory and representative body of the world organisation. Due to the fact that it brings together delegations from all member states of the United Nations, which have equal voting rights in the decision-making process, the General Assembly has taken the form of a

${ }^{13}$ Restricting the veto right according to the Non-Aligned Movement is a key component of Security Council reform. The veto should be limited to vital issues of the international community and Chapter VII of the Charter. Only in the next step should one think about its permanent abolition. In that sense, its rational use includes responsibility and accountability of the expanded composition of the Security Council, i.e. decision-making in the General Assembly in accordance with the Resolution "Uniting for Peace" or on the basis of extensive interpretation of Article 11 and Article 24, paragraph 1 of the United Nations Charter. 
permanent diplomatic conference. Adapting its structure to the requirements of the time, the General Assembly took on a broader responsibility for performing the prescribed functions. This was especially noticeable after the fall of the "Iron Curtain". The new situation directly affected the work and functioning of the General Assembly. In addition to the increased number of delegations of the non aligned member states, which is important in itself, the issues of revitalisation of the work and competencies of the General Assembly were at the centre of attention of the United Nations.

The position of the Non-Aligned Movement towards the process of revitalisation of the General Assembly is reduced to the respected principles of democracy, transparency and accountability. The revitalisation of this main representative body of the world organisation presupposed open and inclusive consultations of non-aligned countries and other member states within the broader process of reforming the United Nations. Given that cohesion between the member states of the Non-Aligned Movement on this issue was quite difficult to achieve, the starting point was to regulate the issue of improving the procedural and working methods of the General Assembly. This issue per se, included issues related to the interpretation of its powers, which are not strictly prescribed by the Charter and which fall within the scope of competence of other bodies of the world organisation. In that sense, the Charter of the United Nations speaks about the general competence of the General Assembly, making a difference in relation to the so-called the subsidiary competence, which has arisen from the practice of the United Nations. Thus, with regard to the maintenance of international peace and security, the General Assembly could not make recommendations on a dispute or situation decided by the Security Council until it had requested it to do so. However, the General Assembly did so in practice, but only in situations when the Security Council, due to the lack of consent of the permanent members, was not able to meet, discuss and make meritorious decisions, i.e. when it was unable to meet its primary obligations under the Charter. These are cases where, due to a Security Council blockade (usually due to the use of vetoes), the General Assembly has been empowered to make recommendations on collective action for serious threats to peace, breaches of peace or acts of aggression, at the request of two-thirds of member states or on the basis of a procedural decision of the Security Council (Jackson, 1983, p. 135). ${ }^{14}$ Expressing great concern at cases in practice where

14 The mentioned procedural rule was adopted on the occasion of the Korean crisis in 1950, when the General Assembly passed the well-known resolution "Uniting 
the Security Council has been paralyzed in making decisions concerning its primary responsibilities (for example, in preventing acts of genocide, crimes against humanity, war crimes or in establishing a ceasefire between warring parties), the Non-Aligned Movement supported the expansion of the competences of the General Assembly. In that sense, the Non-Aligned Movement was primarily guided by the calculation that this more representative body of the world organisation would achieve greater success in overcoming political divisions and inactions that led to the harsh reality of contemporary international relations.

Given the numerous and complex issues that have come under the jurisdiction of the General Assembly over time (areas of international peace, security, political, economic, social, cultural and educational cooperation, codification of international law, human rights and freedoms, etc.), this body had to form a wide network of organs and bodies that assisted him in decision-making. The ability to debate a wide range of issues with a dispersion of powers at multiple organisational levels has, over time, given the impression that the General Assembly has grown into a cumbersome and dysfunctional body unable to focus on the most serious problems in today's world. The adoption of a huge number of legally non-binding resolutions and declarations also contributed to the mentioned impression, which largely led to the decline of the authority of the General Assembly. In the previous period, the reputation of the General Assembly was seriously damaged by an overburdened agenda, lengthy and meaningful debates, slow procedures that often led to the adoption of "already seen" and "recycled" resolutions, without adequate mechanisms for their implementation (Račić, 2010, p. 95). ${ }^{15}$

The reform tendencies in the General Assembly were therefore connected with the question of the legitimacy of the world organisation. The

for Peace", $377(\mathrm{~V})$. Based on this resolution, a rule has been established that the General Assembly may convene an "emergency special session" within 24 hours of receiving a request addressed to the Secretary-General. The resolution did not affect the powers of the Security Council, which remained primarily responsible for maintaining international peace and security.

${ }^{15}$ Hence, it seems that the time has long passed when the General Assembly, with a large majority of member states (including the votes of the non-aligned countries), adopted resolutions such as the Universal Declaration of Human Rights, the Declaration of Principles of International Law concerning Friendly Relations and Cooperation among States in accordance with the Charter of the United Nations, on the Definition of Aggression, etc. 
issue itself is not new and dates back to 1949. Namely, even then, the world organisation tried unsuccessfully to rationalise the procedure and organisation of the General Assembly. In 1952, a Special Committee of Measures was formed, which had the task of assessing the possibility of limiting the time of regular sessions of the General Assembly. In November 1970, the General Assembly formed a number of committees inter alia, including the Special Committee for the Rationalisation of Procedure and the Organisation of its Work. In order to provide a coherent vision that could contribute to the reform of the United Nations in the post-Cold War period, the General Assembly established five working groups in 1992. In August of the following year, it also founded the informal Open-ended Working Group on the Revitalisation of the Work of the General Assembly. At its 1995 session, the General Assembly established a High-Level Working Group to reach a consensus on strengthening the capacity of the world body (GA Res. 49/252, 1995). The Non-Aligned Movement supported the work of this Group, emphasising that its activities should not weaken the development activities of the United Nations system and that its competencies should not overlap with the competencies of existing working groups. In that regard, the Non-Aligned Movement pointed out that it would actively participate in the negotiations with a unified position, acting through the Coordination Bureau, which will consider reports and proposals submitted by various bodies, including non-governmental organisations related to United Nations reform.

In 1997, under the auspices of the General Assembly, an initiative was launched to engage civil society in the debate on the reform of the world organisation. When, during the jubilee 55th Summit in 2000, the issue of world organisation reform was highlighted as one of the Millennium goals, the Secretary General, in order to restore the prestige and vitality of the General Assembly, recommended the establishment of the National Millennium Assembly as a non-governmental forum for cooperation which should act in cooperation with the General Assembly to overcome all future international challenges (UN Doc. A/52/850, 1998). At later sessions, the need to strengthen the role and authority of the General Assembly in order to improve the efficiency and methods of its work was continuously repeated. The Non-Aligned Movement also continuously underlined the importance of revitalizing the General Assembly, and in that sense it formed a special Working Group that would coordinate common issues of interest to the entire Movement (Final Documents, 1998, 2003). 
In a report, In Larger Freedom: Towards Development, Security and Human Rights for All, on 21 March 2005, Secretary-General Kofi Annan proposed steps towards the adoption of a reform package that would lead to the strengthening and revitalisation of the General Assembly (UN Doc. A/59/2005, 2005). ${ }^{16}$ He underlined the importance of harmonizing the work of the General Assembly in order to increase its authority. Annan recommended structural and functional changes to the General Assembly Committee, strengthening the authority of the president, strengthening the role of civil society and changing the agenda. Although the report on the Secretary-General's reform was far from comprehensive, the report was an important step towards reaffirming the role and place of the General Assembly in the United Nations system. After that, at the annual Sessions of the General Assembly, the Non-Aligned Movement encouraged interactive discussions on current issues of importance to the international community. During 2008, an Ad Hoc Working Group on the Revitalisation of the General Assembly was established, with a mandate to "identify additional ways to improve the role, authority, effectiveness and efficiency of the General Assembly" (GA Res. 62/276, 2008). The ad hoc Working Group recommended that the President of the General Assembly engage in an interactive debate on the revitalisation of this body. In September 2010, the General Assembly adopted a resolution reaffirming all its previous decisions relating to the revitalisation of its work. It also decided to form a new ad hoc Working Group that would be open to all Member States. From 2012 onwards, the Working Group was renewed with the task of working on issues of General Assembly reform, especially issues related to the General Assembly's relationship with other major United Nations bodies and groups outside the world organisation, working methods,

${ }^{16}$ In that report, the Secretary-General suggested the adoption of an integrated proposal of the High Level Panel on Threats, Challenges and Change, which, shortly before, in the report: A More Secure World: Our Shared Responsibility, dated 2 December 2004, as part of the implementation of institutional reforms of the world organisation, proposed, among other things, the Human Rights Council which would replace the oft-criticized Human Rights Commission. That proposal was later adopted by General Assembly Resolution no. 60/251 of 15 March 2006. Today, the Non-Aligned Movement supports the work of the Human Rights Council not only through its membership, but also by insisting on its further institutionalisation and constructive approach in promoting and protecting all universally recognised human rights and fundamental freedoms based on the principles of non-selectivity, non-politicization, objectivity and impartiality. 
implementation of resolutions and agendas, the selection and election of the Secretary General, the improvement of the capacity of the Office of the President of the General Assembly, including the strengthening of its institutional memory and its relationship with the Secretariat.

Regarding the above facts, it follows that the process of revitalisation of the General Assembly is not over. The reason for this stems from the lack of political will of all member states to complete the reforms. Changes in international relations have led to a new geopolitical division between states, and instead of the former division into West and East, today there is a division into different interest groups within the Global North and Global South, consisting of coalitions of developed countries on the one side, both underdeveloped and developing countries, on the other side (Group G77, which also includes the members of the Non-Aligned Movement, then a number of countries in transition to which the countries of the European Union from Eastern Europe belong, but also other countries from the profiled sub regional groups). The lack of consensus on the reforms of the General Assembly makes it impossible to effectively solve international problems, and thus significantly complicates the efficient and rational maintenance of peace and security in the world (Dimitrijević, 2014, pp. 23-44).

\section{Reform tendencies in the Economic and Social Council}

From the very beginning of its activities, in addition to preserving international peace and security, which are among its primary obligations and goals, the Non-Aligned Movement also emphasised the obligation to strengthen international cooperation in order to achieve economic and social development and progress (Strydom, 2007, p. 36). The realisation of these obligations is a precondition for the realisation of peaceful and friendly relations between nations, and then for the realisation of all other goals arising from the United Nations Charter. Due to the complexity of development issues, the Movement believes that they do not have to be separated but can be considered in an integral way within the main dimension of development in the General Assembly and the Economic and Social Council (Tadić, 1982; Milinković 1996). In this regard, the NonAligned Movement insists on the restructuring and revitalisation of the United Nations in the economic and social fields so that they can respond to them in an effective manner. The main problem in that context is the dilemma of developing countries, because despite the extreme efforts of millions of people, their position has not significantly improved, but has 
stagnated and is threatening to collapse in some fields. Hence, it is considered necessary to accelerate the reform process so that the UN mechanism, primarily the Economic and Social Council, can respond to the growing needs of the Third World countries. In this regard, the General Assembly adopted Resolution 61/16 on the strengthening of the Economic and Social Council of 20 November 2006, reaffirming the need to meet the commitments made in the United Nations Millennium Declaration, the Monterey Consensus of the International Conference on Financing for Development and the Plan of Implementation of the World Summit on Sustainable Development (Johannesburg Plan of Implementation), as well as the agreement reached at the World Summit in 2005, in the economic, social and related fields (Final document, 2019).

As is well known, the United Nations is acting in accordance with the objectives set out in Chapter IX of the Charter, which relate, inter alia, to the promotion of international economic and social cooperation by increasing living standards, full employment and conditions for economic and social progress, social, health and related issues, promotion of international cultural and educational cooperation and respect for human rights and fundamental freedoms. In order to create the conditions of stability and prosperity necessary for peaceful and friendly relations between States, the United Nations has entrusted the implementation of these objectives, primarily to the General Assembly and under its auspices - the Economic and Social Council, which has the powers set out in Chapter X of the Charter. As one of the main bodies of the United Nations, the Economic and Social Council has the opportunity to study and prepare reports on international economic, social, cultural, educational, health and related issues. The Council also has the possibility of making certain recommendations to the General Assembly, Member States and interested specialized agencies. It may convene international conferences and prepare draft conventions for submission to the General Assembly. Also, the Economic and Social Council may conclude agreements with specialized agencies which regulate in more detail the issues of connecting agencies with the world organisation. It may also provide services to Member States and specialized agencies and conclude consultancy agreements with interested organisations. The Economic and Social Council is assisted in its work by nine functional commissions for various fields (statistics, forestry, prevention and criminal justice, the fight against narcotics, social development, science and technology, sustainable development, women's rights, population, etc.). At the regional level, the Council is assisted by five commissions: the Economic Commission for Africa (based in Addis Ababa), the Economic and Social 
Commission for Asia and the Pacific (based in Bangkok), the Economic Commission for Europe (based in Geneva), the Economic Commission for Latin America and the Caribbean (based in Santiago de Chile) and the Economic and Social Commission for Western Asia (based in Beirut). In cases where the need arises, the Economic and Social Council is assisted by other bodies (Basic Facts about the UN, 2011, p. 14).

Since the beginning of the work of this United Nations body, there have been several proposals for its structural reform. Thus, with the entry into force of the Charter on October 24, 1945, there were 18 members in the Economic and Social Council elected by the General Assembly. With the increase in the number of members of the world organisation, a proposal was made to reform the composition of this body. By Resolution of the General Assembly 1991B (18) of 17 December 1963, this proposal was adopted by amending Article 61 of the Charter and increasing the number of members of the Economic and Social Council to 27. The next reform amendment to Article 61 of the Charter was based on a resolution of the General Assembly 2847 (XXVI) of 20 December 1971, when the number of members was increased to 54 . Given that each member of the Economic and Social Council had one representative in the Council, and that each of them had one vote, with the new reform solution that came into force on 24 September 1973, the representation of states was to be somewhat fairer because 14 members represented Africa, 10 members - America and the Caribbean, 13 members - Western Europe and other countries and 6 members - Eastern Europe (Kreća, 2007, p. 507). However, although the members of the Council were elected on the basis of geographical representation, and decisions in the Council were made by a majority vote of the members present and voting, the adopted reform proposals due to the present political opportunity did not prove fair enough. Therefore, the General Assembly soon adopted Resolution 32/197 of 20 December 1975, in order to make the functioning of the Economic and Social Council somewhat more effective and efficient. Namely, referring to the previously voted resolutions on the establishment of the New Economic Order and the Charter on the Economic Rights and Duties of States, the General Assembly, at the suggestion of the ad hoc Committee on Restructuring the Economic and Social Sector of the United Nations, proposed strategic priorities for the Council and the social sphere in the coming period (Bulajić, 1980, pp. 6882; GA Res. 3201 (S-VI), 1974; GA Res. 3202 (S-VI), 1974; GA Res. 3281 (XXIX, 1974). Priorities included coordinating the work of the General Assembly and the Economic and Social Council, as well as improving the efficiency of the entire United Nations system in the field of international economic 
cooperation (Luck, 2003). At the end of the 1980s, there was a new rift between the group of developed and developing countries. Thus, Group 77 submitted several draft resolutions to the General Assembly proposing the introduction of universal membership in the Economic and Social Council. Due to the opposition of a group of developed countries (especially the permanent members of the Security Council), the draft resolutions did not pass the voting procedure. Consequently, during the 50th session of the 1996 General Assembly, Resolution 50/227 was passed, setting out new demands for the strengthening of the Economic and Social Council. In order to further restructure and revitalize the United Nations system, the General Assembly recommended that the Economic and Social Council continue to strengthen its role as a central mechanism for coordinating the activities of the world organisation and its specialized agencies and as a body responsible for overseeing subsidiary bodies and functional bodies. It also recommended that the Council continue to coordinate activities related to the realisation of the results achieved at the most important international conferences in the economic and social field. In the later period, these recommendations were joined by another one related to taking over the role in the field of Global Economic Governance (A Background Document, 2003).

The second round of important reforms of the Economic and Social Council was launched during the 57th session of the General Assembly in 2003, when the ad hoc Working Group submitted a motion for a resolution on the coordinated and integrated implementation and monitoring of United Nations conferences. The General Assembly adopted the proposal and passed Resolution 57/270B entrusting the role of implementing and monitoring the achieved results in the management of the world development process to the Economic and Social Council and its subsidiary bodies (above all, functional-technical and regional commissions), and then to the bodies, funds and programs established by its organisations. Despite the progress made in the 1990s, the efficiency and effectiveness of the Economic and Social Council were unsatisfactory, and the conclusions of the 2005 jubilee summit of the General Assembly, paragraphs 155 and 156, mention the need to further strengthen the Economic and Social Council as well as the adaptation of its functional competencies in order to meet the set development goals. In the continuation of the summit, the General Assembly adopted several resolutions, among which, perhaps, the most important is Resolution. 61/16 of 20 November 2006. The resolution reaffirms the need to strengthen the Economic and Social Council through an annual ministerial substantive review of the report on the implementation of the Development Agenda, including the United Nations 
Millennium Development Goals. The resolution also instructs the Council to hold a development cooperation forum every other year and to monitor trends and progress in the development of international cooperation, i.e. to monitor the regulation of aid quality and quantity, and to provide guidelines on practical measures and policy options on how to improve coherence and effectiveness of his work. Immediately after the adoption of the said resolution, the Council adopted Decision E / 2006/274 of 15 December 2006, which provided additional modalities for its involvement in the preparation of the said meetings. On that occasion, the Council specifically referred to: "The role of the United Nations system in promoting full and productive employment and decent work for all" After that period, the Economic and Social Council was the subject of consultations on a comprehensive reform of the United Nations system. In particular, these consultations considered the possibility of adopting a new resolution that would elaborate on the earlier progress made by General Assembly Resolution 61/16 of 20 November 2006 and Decision E/2006/206 of 10 February 2006, which concerned the harmonization of its working methods (A/RES/61/16, 2007; E/2006/206, 2006).

With the outbreak of the global economic crisis, the focus of economic problems shifted to the G20. The attitudes of some developing countries that global economic problems should be solved outside the United Nations system, which further raised questions about Global Governance, also contributed to the situation. The role of the Economic and Social Council was elaborated at the conference of the United Nations General Assembly held in July 2009, which was dedicated to financial and economic crises. The Member States, including the members of the Non-Aligned Movement, agreed on the need to support a coordinated responsibility for the development of the United Nations system through the adoption of adopted documents to help consensus on policies related to the global economic and financial crisis and their impact on development. At the conference, the Economic and Social Council was asked to send recommendations to the General Assembly in accordance with the provisions of the Doha Declaration adopted on 2 December 2008, on the occasion of strengthening the process of financing development. Also, the Council was required to examine the possibility of strengthening institutional arrangements to promote international cooperation in the field of fiscal policy, as well as in the field of cooperation with international financial institutions. After that, the General Assembly adopted Resolution 63/303 of 13 July 2009, which recommended the establishment of an ad hoc Panel of Experts to analyse and provide technical expertise on overcoming the global economic and financial 
crisis (A/RES/63/303, 2009). The impact of the global crisis has obviously led to the marginalization of the Economic and Social Council. It has become more of a forum for discussion on the Development Agenda and the Millennium Development Goals between the countries of the South, which have not joined the developed countries of the Global North that advocate resolving the world's most important economic issues outside the United Nations institutional framework. Certain constraints arising from the structure of the world economy, changing interests of developing countries, and still-present ideological conflicts among the world organisation's member states all contributed to this situation. In order to regain its authority as the principal body of the United Nations for the promotion of international economic cooperation, coordination, policy review, policy dialogue and formulation of recommendations on issues of economic and social development, the Economic and Social Council will have to hold open discussions with other bodies of the world organisation and to develop cooperation with international financial institutions and the World Trade Organisation (Chimni, 2011, pp. 48-54). The reaffirmation of its place and role in the international order will depend, among other things, on its ability to review and assess the balanced integration of the pillars of sustainable development and their impact on the full implementation of international development goals.

\section{Conclusions}

The study on the role of the Non-Aligned Movement in the reform of the United Nations provides general information on the genesis of proposals for the reorganisation of the main bodies of the world organisation - the Security Council, the General Assembly and the Economic and Social Council. These proposals were generated within the final reports of the NonAligned Movement Summit, and then in the reports of the working groups established by the General Assembly. Some constructive and concrete proposals on reform processes have also come from the Secretaries General. The range of proposed reform models for the main bodies of the world organisation indicates the fact that the reform process is developing in parallel with a more subtle process of change in contemporary international relations. The discussion on the reform of the Security Council, the General Assembly, the Economic and Social Council is therefore more serious and sophisticated than it initially seems with the mandate of drafting concrete reform proposals. The analysis shows that the United Nations remains an indispensable multilateral mechanism of the member states of the Non- 
Aligned Movement for solidarity in solving all their most important problems. Although the main bodies of the world organisation are rapidly changing their characteristics that go beyond their traditionally established legal frameworks, overcoming this difference is connected with the dynamics of the development of international relations. All the more so, efforts to reform the United Nations for the non-aligned countries represent a major investment that requires both a conceptual transformation of the Non-Aligned Movement and a methodological adaptation to possible structural and functional changes in the major organs of the world organisation. For the Non-Aligned Movement, the United Nations, with its principal organs, remains the most appropriate international forum for preserving peace and security and for achieving fairer and more equitable economic and social relations. For the Non-Aligned Movement, the United Nations, with its principal organs, remains the most appropriate international forum for preserving peace and security and for achieving fairer and more equitable economic and social relations. Only through the United Nations system can the Non-Aligned Movement influence the formation of a new international order based on law and justice, as well as on other leading goals and principles of active peaceful coexistence among nations and states. The determination of the Non-Aligned Movement to play a vital role in the revival, reconstruction and democratisation of the world organisation speaks in favour of the acceptance of the universal values contained in the aims and principles of the United Nations Charter. Finally, despite the fact that there are some disagreements about the reform of the United Nations among the non-aligned states, the United Nations for all of them remains a significant factor in international relations and a place where their needs and attitudes are articulated as the needs and attitudes of the majority of the international community, which just personifies the NonAligned Movement itself.

\section{References}

A Background Document (2003). “Globalization and Non-Aligned Movement an Economic Agenda for Action". Document for the XIII NAM Summit Kuala Lumpur, Malaysia 20-25 February 2003, retrieved from: http:// ris.org.in/images/RIS_images/pdf/Executive $\% 20$ Summary $\% 20$ of $\%$ 20\%20XIII\%20NAM\%20Summit.pdf

Adapting the work of the Economic and Social Council. (2006). ECOSOC Decision E/2006/206, 10 February. 
An Agenda for Peace Preventive Diplomacy, Peace-making and Peacekeeping. (1992). Report of the Secretary-General pursuant to the Statement adopted by the Summit Meeting of the Security Council on 31 January 1992, UN Doc. A/47/277 - S/24111, 17 June.

An Agenda for Development. (1993). Report of the Secretary-General, UN Doc. A/48/935, 6 May.

Avramov, Smilja (1965). „Proširenje Saveta bezbednosti i Ekonomskog i socijalnog saveta $\mathrm{UN}^{\prime \prime}$, Jugoslovenska revija za medunarodno pravo, 2-3.

Basic Facts about the United Nations. (2011). New York, UN Department of Public Information.

Bartoš, Milan. (1955). „Povelja OUN i dužnost aktivne koegzistencije”, Međunarodna politika, 126-128.

Blagović, Božica. (1973). „Idejne osnove miroljubive aktivne koegzistencije”, u: Nesvrstanost, osnovi jedne doktrine međunarodne politike. Beograd, Radnička štampa.

Blokker, Niels. (2000). "Is the Authorization Authorized? Powers and Practice of the UN Security Council to Authorize the Use of Force by 'Coalitions of the Able and Wiling'" , European Journal of International Law, 2000, 11(3).

Bogetić, Dragan. (2019). Nesvrstanost kroz istoriju. Beograd, Zavod za udžbenike.

Bowet, Derek. (1994). „,The Impact of Security Council Decisions on Dispute settlement Procedures", European Jounal of International Law, 5.

Bulajić, Milan. (1980). Međunarodno pravo ekonomskog razvoja. Beograd, Savez udruženja pravnika Jugoslavije.

Charter of Economic Rights and Dutiese of States. (1974). GA Res. 3281 (XXIX), 12 December.

Chimini, B.S. (2011). "ECOSOC and International Economic Institutions", in: (Ralph Wilde ed.), United Nations Reform Through Practice, Report of the International Law Association Study Group on United Nations Reform. 11 December, retreived from: https://papers.ssrn.com/sol3/ papers.cfm?abstract_id $=1971008$

Damian Lakićević, Ana (2009). „Izgledi za obnavljanje saradnje Srbije sa Pokretom nesvrstanosti", Međunarodni problemi, LXI(4).

Declaration and the Programme of Action on the Establishment of a New International Economic Order. (1974). GA Res. 3201 (S-VI) and GA Res. 3202 (S-VI), 1 May. 
Dimić, Ljubodrag. (2011). “Towards the Belgrade conference, Yugoslavia and the beginnings of the Non-Aligned Movement", in: Nada Pantelić, Dušan Jončić (eds), The First Conference of Heads of State or Government of Non-Aligned Countries, Belgrade 1961, Belgrade, Archives of Yugoslavia. The Ministry for Foreign Affairs of the Republic of Serbia.

Dimitrijević, Duško. (2006). „,Reforma kolektivne bezbednosti Ujedinjenih nacija“",Međunarodna politika, 2005-2006, 1120-1121.

Dimitrijević, Duško. (2009). Reforma Saveta bezbednosti Ujedinjenih Nacija, Beograd, Institut za međunarodnu politiku i privredu.

Dimitrijević, Duško. (2009). „Modeli reorganizacije Saveta bezbednosti Ujedinjenih nacija“", Pravni život, V(13).

Dimitrijević, Duško. (2014). „Reforme Ujedinjenih nacija - Generalna skupština, Ekonomski i socijalni savet i administrativni aparat", u: Dragoljub Todić i Marko Novaković (eds.), Savremeni međunarodnopravni poredak $i$ evropske integracije Srbije, Beograd, Institut za međunarodnu politiku i privredu.

Dupuy, Pierre Maria. (1997). “Constitutional Dimension of the Charter of the United Nations Revisited" Max Planck Yearbook of United Nations Law, 1.

Fassbender, Bardo. (2005). "UN Reform and Collective Security The Report of the 'UN High-level Panel on Threats, Challenges and Change", Global Issue Papers, 17.

Final document. (1961). 1st Summit Conference of Heads of State or Government of the Non-Aligned Movement. Belgrade, Serbia 6 September 1961, retrieved from: http://cns.miis.edu/nam/documents /Official_Document/1st_Summit_FD_Belgrade_Declaration_1961.pdf

Final document. (1964). 2nd Summit Conference of Heads of State or Government of the Non-Aligned Movement Cairo, Egypt 10 September 1964, retrieved from: http://cns.miis.edu/nam/documents/Official _Document/2nd_Summit_FD_Cairo_Declaration_1964.pdf

Final document. (1970). 3rd Summit Conference of Heads of State or Government of the Non-Aligned Movement Lusaka, Zambia 8-10 September 1970, retrieved from: http:/ /cns.miis.edu/nam/documents/ Official_Document/3rd_Summit_FD_Lusaka_Declaration_1970.pdf

Final document. (1973). 4th Summit Conference of Heads of State or Government of the Non-Aligned Movement Algiers, Algeria 5-9 September 1973, retrieved from: http://cns.miis.edu/nam/documents/ Official_Document/4th_Summit_FD_Algiers_Declaration_1973_Whole. pdf 
Final document. (1976). 5th Summit Conference of Heads of State or Government of the Non-Aligned Movement Colombo, Sri Lanka 16-19 August 1976, retrieved from: http://cns.miis.edu/nam/documents/ Official_Document/5th_Summit_FD_Sri_Lanka_Declaration_1976_Wh ole.pdf

Final document. (1979). 6th Summit Conference of Heads of State or Government of the Non-Aligned Movement Havana, Cuba 3-9 September 1979, retrieved from: http://cns.miis.edu/nam/documents/ Official_ Document/6th_Summit_FD_Havana_Declaration_1979_Whole.pdf

Final document. (1983). 7th Summit Conference of Heads of State or Government of the Non-Aligned Movement New Delhi, India 7-12 March 1983, retrieved from: http://cns.miis.edu/nam/documents/ Official_Document/7th_Summit_FD_New_Delhi_Declaration_1983_W hole.pdf

Final document. (1986). 8th Summit Conference of Heads of State or Government of the Non-Aligned Movement Harare, Zimbabwe 1-6 September 1986, retrieved from: http://cns.miis.edu/nam/documents/ Official_Document/8th_Summit_FD_Harare_Declaration_1986_Whole. pdf

Final document. (1989). 9th Summit Conference of Heads of State or Government of the Non-Aligned Movement Belgrade, Serbia 4-7 September 1989, retrieved from: http://cns.miis.edu/nam/documents/ Official_Document/9th_Summit_FD_Belgrade_Declaration_1989_Whol e.pdf

Final document. (1992). 10th Summit Conference of Heads of State or Government of the Non-Aligned Movement Jakarta, Indonesia 1-6 September 1992, retrieved from: http://cns.miis.edu/nam/documents/ Official_Document/10th_Summit_FD_Jakarta_Declaration_1992_Whol e.pdf

Final document. (1995). 11th Summit Conference of Heads of State or Government of the Non-Aligned Movement Cartagena, Colombia 1820 October 1995, retrieved from: http://cns.miis.edu/nam/documents/ Official_Document/11th_Summit_FD_Cartagena_Declaration_1995_W hole.pdf

Final document. (1998). 12th Summit Conference of Heads of State or Government of the Non-Aligned Movement Durban, South Africa 29 August - 3 September 1998, retrieved from: http://cns.miis.edu/ 
nam/documents/Official_Document/12th_Summit_FD_Durban_Decla ration_1998.pdf

Final document. (2003). 13th Summit Conference of Heads of State or Government of the Non-Aligned Movement Kuala Lumpur, Malaysia 24-25 February 2003, retrieved from: http://cns.miis.edu/ nam/documents/Official_Document/13th_Summit_of_the_NonAligned_Movement_-_Final_Document_Whole.pdf

Final document. (2006). 14th Summit Conference of Heads of State or Government of the Non-Aligned Movement Havana, Cuba 11-16 September 2006, retrieved from: http://cns.miis.edu/nam/documents /Official_Document/14NAMSummit-Havana-Compiled.pdf

Final document. (2009). 15th Summit Conference of Heads of State or Government of the Non-Aligned Movement Sharm el-Sheikh, Egypt 11 - 16 July 2009, retrieved from: http://cns.miis.edu/nam/documents/ Official_Document/15Summit-Final-_Compiled.pdf

Final document. (2012). 16th Summit of Heads of State or Government of the Non-Aligned Movement Tehran, Islamic Republic of Iran 26 - 31 August 2012, retrieved from: http://cns.miis.edu/nam/documents/ Official_Document/16thSummitFinalDocument(NAM2012-Doc.1Rev.2).pdf

Final document. (2016). 17th Summit of Heads of State and Government of the Non-Aligned Movement Island of Margarita, Bolivarian Republic of Venezuela 17-18 September 2016, retrieved from: http://cns.miis. edu/nam/documents/Official_Document/XVII-NAM-Summit-FinalOutcome-Document-ENG.pdf

Final document. (2019). 18th Summit of Heads of State and Government of the Non-Aligned Movement. Baku, the Republic of Azerbaijan, 25-26 October 2019, retrieved from: https:/ /www.unidir.org/sites/default/ files/2020-10/2019_NAM\%20Summit\%20final\%20doc.pdf

GA Res. 49/252. (1995). United Nations General Assembly, 14 September. GA Res. 62/276. (2008). United Nations General Assembly, 26 September. In Larger Freedom: Towards Development, Security and Human Rights for All. (2005). Report of Secretary General, UN Doc. A/59/2005, 21 March. Jackson, Richard L. (1983). The Non-Aligned, the UN and the Superpowers. New York, Preager Publishers. 
Jovanović, Jadranka. (1989). „Sastav Saveta bezbednosti i problemi izbora nestalnih članova: Neka jugoslovenska iskustva“ ", Međunarodni problemi, 2-3.

Komatina, Miljan. (1980). "Policy and Movement of Non-Alignment and the United Nations", Review of International Affairs, 5.

Kumar Jha, Sanjay. (1994). International Politics in the Third World, New Delhi, Anmol Publications.

Luck, Edward C. (2003). "Reforming the United Nations: Lessons from a History in Progress", Occasional Papers Series, Academic Council on the United Nations System.

Mates, Leo. (1970). Nesvrstanost, teorija i savremena praksa. Beograd, Institut za međunarodnu politiku i privredu.

Mates, Leo. (1974). Koegzistencija. Zagreb, Školska knjiga.

Mikhailtchenko, Maria. (2004). "Reform of the Security Council and its implications for Global Peace and Security", Journal of Militay and Strategic Studies. 7(1).

Milinković, Branislav. (1996). Nesvrstanost u poshladnoratovskoj eri, Beograd, Međunarodna politika, Službeni list, Pravni fakultet, Fakultet političkih nauka, Institut ekonomskih nauka, Institut za međunarodnu politiku i privredu.

Müller, Joachim M. (1997). Reforming the United Nations: New Initiatives and Past Efforts, Kluwer Law International, 1997, I.

Outcome of the Conference on the World Financial and Economic Crisis and Its Impact on Development. (2009). United Nations General Assembly. A/RES/63/303, 9 July 2009.

Petković, Ranko. (1974). Teorijski pojmovi nesvrstanosti. Beograd, Rad.

Račić, Obrad. (2010). Ujedinjene nacije između moći i prava, Beograd, Službeni glasnik.

Report of the Open-ended Working Group. (2001). The Open-ended Working Group on the Question of Equitable Representation on and Increase in the Membership of the Security Council and other Matters related to the Security Council, General Assembly Official Records, Fiftyfifth Session Supplement No. 47 (A/55/47), United Nations, New York, Annex XIII.

Strengthening of the Economic and Social Council. (2007). United Nations General Assembly. A/RES/61/16, 20 November 2006.

UN Doc. A/52/850. (1998). United Nations General Assembly, 31 March. 
Winkelmannm, Ingo (1997). "Bringing the Security Council into a New Era, Recent Developments in the Discussion on the Reform of the Security Council", Max Planck Yearbook of United Nations Law, 1997, 1.

World Summit Outcome Document. (2005). UN Doc. A/RES/60/1.

Strydom, Hennie. (2007). "The Non-Aligned Movement and the Reform of International Relations", Max Planck Yearbook of United Nations Law, 11(1).

Tadić, Bojana. (1976). Nesvrstanost u teoriji i praksi međunarodnih odnosa, Beogad, Institut za međunarodnu politiku i privredu.

Tadić, Bojana. (1982). Nesvrstanost i dileme nesvrstanosti. Beograd, Izdavački centar Komunist.

Stojanović, Radoslav (1981). "The Emergence of the Non-Aligned Movement: A View from Belgrade", Case Western Reserve Journal of International Law, 13(3).

Šahović, Milan. (1998). “Le role de la Charte des Nations Unies dans le development du Droit International en Avenir", Thesaurus Acroasium, 27.

Šahović, Milan.(2005). „Šezdeseta godišnjica u znaku reforme Ujedinjenih nacija“, Međunarodna politika, 1118-1119. 